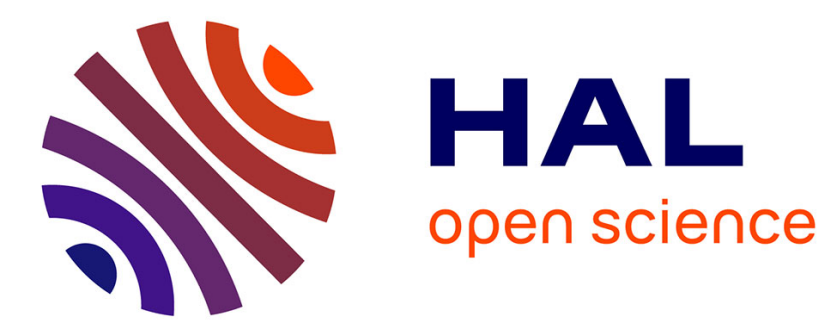

\title{
GPR MURAL STUDY OF THE COMMANDERY OF JALÈS (FRANCE)
}

Christophe Benech, Quentin Vitale, Laurent d'Agostino, Côme Parfant

\section{To cite this version:}

Christophe Benech, Quentin Vitale, Laurent d'Agostino, Côme Parfant. GPR MURAL STUDY OF THE COMMANDERY OF JALÈS (FRANCE). Archeosciences, revue d'Archéométrie, 2021, XIVth International Conference of Archaeological Prospection, 45 (1), pp.157-159. 10.4000/archeosciences.9253. halshs-03362302

\section{HAL Id: halshs-03362302 \\ https://shs.hal.science/halshs-03362302}

Submitted on 1 Oct 2021

HAL is a multi-disciplinary open access archive for the deposit and dissemination of scientific research documents, whether they are published or not. The documents may come from teaching and research institutions in France or abroad, or from public or private research centers.
L'archive ouverte pluridisciplinaire HAL, est destinée au dépôt et à la diffusion de documents scientifiques de niveau recherche, publiés ou non, émanant des établissements d'enseignement et de recherche français ou étrangers, des laboratoires publics ou privés. 


\title{
GPR MURAL STUDY OF THE COMMANDERY OF JALÈS (FRANCE)
}

\author{
Christophe Benech, Quentin Vitale, Laurent d'Agostino, Côme Parfant
}

Presses universitaires de Rennes | « ArcheoSciences »

2021/1 n 45-1 | pages 157 à 159

ISSN 1960-1360

ISBN 9782753585874

DOI 10.4000/archeosciences.9253

Article disponible en ligne à l'adresse :

https://www.cairn.info/revue-archeosciences-2021-1-page-157.htm

Distribution électronique Cairn.info pour Presses universitaires de Rennes.

(C) Presses universitaires de Rennes. Tous droits réservés pour tous pays.

La reproduction ou représentation de cet article, notamment par photocopie, n'est autorisée que dans les limites des conditions générales d'utilisation du site ou, le cas échéant, des conditions générales de la licence souscrite par votre établissement. Toute autre reproduction ou représentation, en tout ou partie, sous quelque forme et de quelque manière que ce soit, est interdite sauf accord préalable et écrit de l'éditeur, en dehors des cas prévus par la législation en vigueur en France. Il est précisé que son stockage dans une base de données est également interdit. 


\section{ArcheoSciences}

Revue d'archéométrie

45-1 | 2021

14th International Conference of Archaeological Prospection

\section{GPR Mural Study of the Commandery of Jalès (France)}

Christophe Benech, Quentin Vitale, Laurent d'Agostino and Côme Parfant

\section{(2) OpenEdition}

Journals

Electronic version

URL: https://journals.openedition.org/archeosciences/9253

DOI: 10.4000/archeosciences.9253

ISSN: 2104-3728

\section{Publisher}

Presses universitaires de Rennes

\section{Printed version}

Date of publication: 16 August 2021

Number of pages: 157-159

ISBN: 978-2-7535-8587-4

ISSN: 1960-1360

Electronic distribution by Cairn

\section{CAIRN INFO}

CHERCHER, REPÉRER, AVANCER.

\section{Electronic reference}

Christophe Benech, Quentin Vitale, Laurent d'Agostino and Côme Parfant, "GPR Mural Study of the Commandery of Jalès (France)", ArcheoSciences [Online], 45-1 | 2021, Online since 16 August 2021, connection on 30 August 2021. URL: http://journals.openedition.org/archeosciences/9253 ; DOI: https://doi.org/10.4000/archeosciences.9253 


\title{
GPR Mural Study of the Commandery of Jalès (France)
}

\author{
Christophe Benech ${ }^{a}$, Quentin Vitale ${ }^{b}$, Laurent D'Agostino ${ }^{c}$ and Côme Parfant ${ }^{d}$
}

\author{
Highlights: \\ - Use of high resolution GPR mapping for the study of masonry walls. \\ - Delineation of underlying the main characteristics of the wall. \\ - Evaluate the different steps of renovation and/or partial reconstruction of the wall.
}

Keywords: GPR, masonry study, Heritage archaeology, medieval building, high resolution.

\section{INTRODUCTION}

The commandery of Jalès is located in France, at the eastern limit of Cevennes Mountains, in the South of Ardèche (Fig. 1). This establishment was founded by the Templar order during the second third of the $12^{\text {th }}$ century and was continuously occupied until nowadays. From 2017 to 2020, an interdisciplinary research project was launched to study the history of the monument, including archaeology, GIS, photogrammetry, 3D modelling, dendrochronology and geophysics (D’Agostino et al., 2019).

The commandery is composed of several buildings testifying of the permanent evolution of the organization of the whole establishment and can be considered as one of the most well preserved commandery of the region. During its long history, the architectural ensemble has undergone numerous renovations, reconstructions or extensions which have profoundly modified the original plan. The main building in particular retains many testimonies of this perpetual evolution: unplastered walls make it possible to identify different types of modules in the blocks used, as well as traces of windows, doors or arches which by the suite were clogged. Some plastered walls do not allow such an in-depth study to be carried out. Moreover, it can also be interesting to study the structure of a wall beyond its exterior facing which can sometimes mask an older condition.

The objective of this study is to estimate the type of information that can be acquired by onwalls ground-penetrating radar (GPR) mapping to supplement the archaeological information of the building. The GPR has been used since several years on the monuments for different purposes (Angelis et al., 2018). Most of these applications served to analyze the structure of the walls in a heritage context of the conservation of the monuments (Ferrara \& Barone, 2015). The aim of this research is to evaluate the contribution of a GPR survey for the study of the different phases of the monuments through the characteristics of the walls.

\section{Material AND METHOD}

A reconnaissance of several plastered walls of the commandery was carried out using a pulse $\mathrm{EKKO}^{\circledR}$ Pro system (Sensors \& Software) associated with a TR1000 antenna

\footnotetext{
${ }^{a}$ Corresponding author, Université de Lyon, CNRS, Archeorient, UMR 5133, Maison de l'Orient et de la Méditerranée, France

${ }^{\mathrm{b}}$ Éveha International, 161 avenue de Verdun, 94200 Ivry-sur-Seine, France, Université de Lyon, CNRS, Archeorient, UMR 5133, Maison de l'Orient et de la Méditerranée, France

'Atelier d'Archéologie Alpine

d Université de Lyon, CNRS, Archeorient, UMR 5133, Maison de l'Orient et de la Méditerranée, France
} 


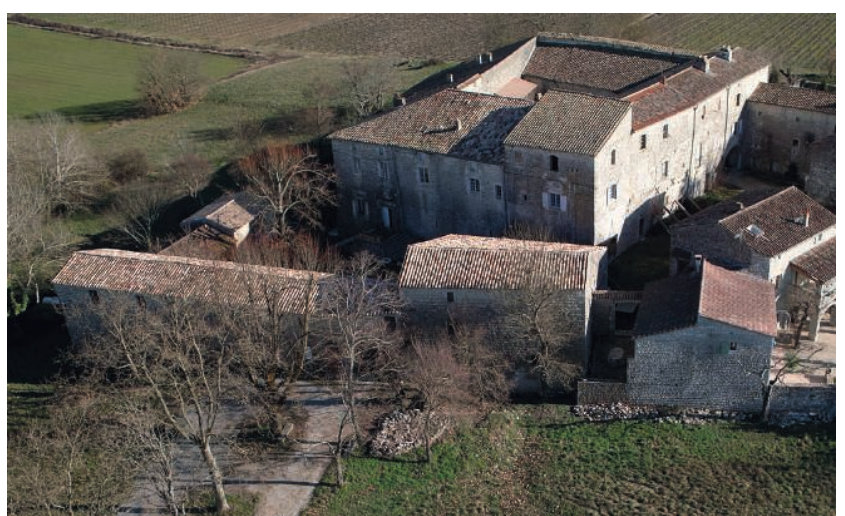

Figure 1. The main building of the commandery of Jalès (ㄷ Photo O. Barge).

(center frequency of $1 \mathrm{GHz}$ ) which allows an investigation depth of around $1 \mathrm{~m}$. In order to position the measurements and achieve the most regular survey grid possible, an actual grid was drawn on a flexible plastic support. This transparent support was placed on the walls during the survey (Fig. 2). The horizontality of the measurement grid is ensured by a simple spirit level. This grid makes it possible to produce measurement profiles every $5 \mathrm{~cm}$. To ensure the finest sampling possible, each zone was surveyed in both horizontal and vertical directions.

These initial tests provided interesting information on the structure of the walls at different depths. The most superficial maps, around $5 \mathrm{~cm}$ depth, allow the characteristics of the exterior facing to be recognized: masonry seals are relatively clearly visible and make it possible to identify the size of the blocks and therefore the differences in the type of brickwork used. The blockages that affected the last condition of the wall before it was plastered are also easily identifiable.

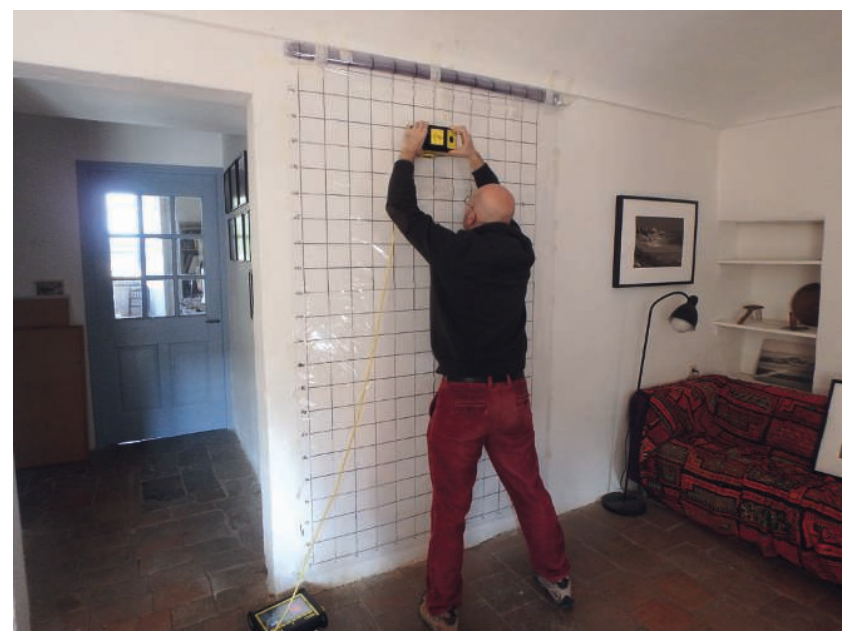

Figure 2. GPR survey with the pulseEKKO TR1000 on a $5 \mathrm{~cm}$ mesh grid.

\section{RESUlTS}

At about $25 \mathrm{~cm}$ depth, the radar signal makes it possible to visualize the state of the wall beyond the exterior facing and therefore to highlight elements which would not have been visible even if the wall had not been plastered (Fig. 3). Older elements, such as arches or stone courses appear clearly as highly reflective features. Other reflections have less geometric shapes but also seem to show heterogeneous fillings between the two facings.

These first results clearly show the significant contribution of the GPR survey for an architectural study. Beyond the identification of obstructed doors or windows, a high resolution GPR survey succeeds to identify the different modules used in the construction of the walls which is a key information for the determination of the chronology of the construction.

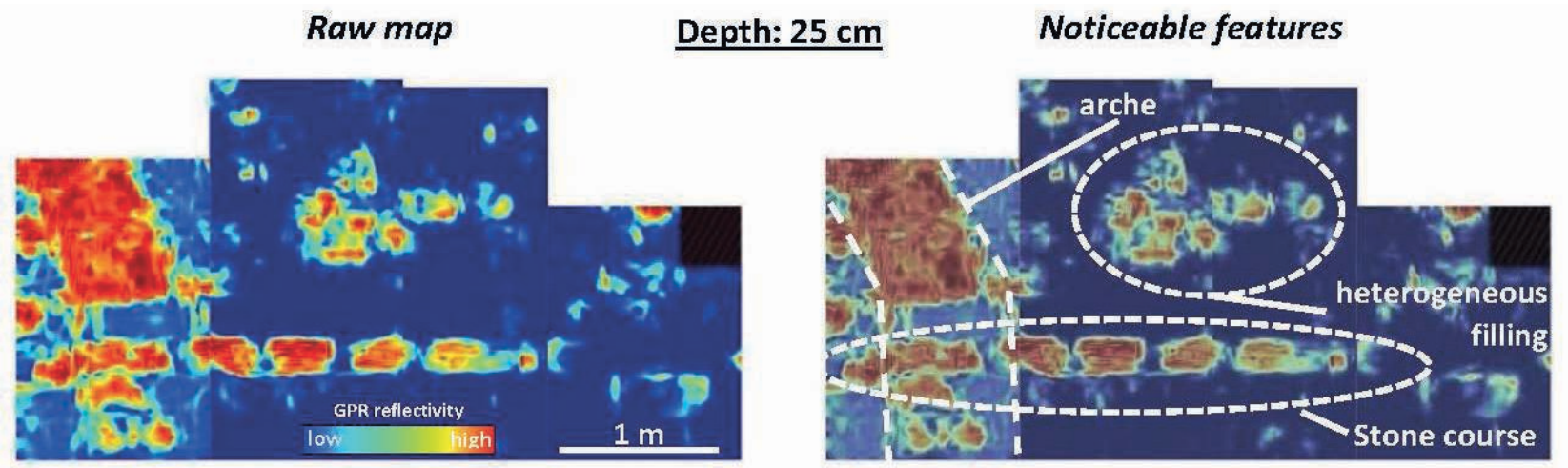

Figure 3. Example of result obtained on the walls of the commandery: the traces of an arch appear at $25 \mathrm{~cm}$ depth inside the wall. The color coding for the reflectivity values goes from red for high values to blue for low values. 


\section{References}

Angelis, D., Tsourlos, P., Tsokas, G., Vargemezis, G., Zacharopoulou, G., Power, C., 2018. Combined application of GPR and ERT for the assessment of a wall structure at the Heptapyrgion fortress (Thessaloniki, Greece). Journal of Applied Geophysics, 152: 208-220. DOI : 10.1016/j.jappgeo.2018.04.003.

D’Agostino, L., Régagnon, E., Barge, O., Benech, C., ChauvinDesfleurs, E., Crépy, M., Maréchal, É., Saison, A., Vitale, Q.,
Wicha, S., 2019. La commanderie de Jalès, Berrias et Casteljau (Ardèche). Un établissement des ordres religieux militaires en Cévennes, Projet Collectif de Recherche (2017-2020). Rapport de Campagne 2019. Report. Atelier d'Archéologie Alpine ; Archéorient CNRS ; Conseil départemental de l'Ardèche. URL: https://hal.archives-ouvertes.fr/hal-02511702.

Ferrara, C., Barone, P.M., 2015. Detecting Moisture Damage in Archaeology and Cultural Heritage: a Brief Introduction. International Journal of Archaeology, 3(1): 57. DOI: 10.11648/j.ija.s.2015030101.17. 